Jurnal Riset Manajemen dan Akuntansi

Volume 1 - No.2, Oktober 2014

\title{
PENGARUH PENDAPATAN OPERASIONAL UTAMA TERHADAP RETURN ON ASSET ( ROA) PADA PT. BANK SYARI'AH MANDIRI
}

\author{
Afriyeni \\ STIE "KBP” Padang \\ (afriyeni.yen@gmail.com)
}

\begin{abstract}
This study aims to determine the effect of the sale revenue, revenue sharing, and rental income partially and simultaneously to return on assets (ROA) in Shariah Mandiri Bank Jakarta. To analyze the data (annual financial statements from 2005-2009)used descriptive statistics, correlation analysis and multiple regression analysis. Regression results using a significant level of $\alpha=5 \%$, and the results of this study demonstrate that the partial sale of revenue, revenue-sharing and rental income no significant effect on return on assets (ROA), with each sig is above 0,05 ie 0.584, 0.74, and 0.859. Simultaneous independent variables (income buying and selling, sharing revenues and rental income) also did not significantly influence (dependent variable) is return on assets (ROA), with sig 0.351 which is above 0.05.
\end{abstract}

Keywords: return on assets, income buying, selling, sharing revenues, rental income

\section{PENDAHULUAN}

Pendapatan

(Revenue) pada perbankan syari'ah merupakan hasil yang diterima oleh bank dari penyaluran dana (investasi) ke dalam bentuk aktiva produktif, yaitu penempatan dana bank pada pihak lain. Dalam bank syari'ah sumber pendapatan operasi utamanya adalah : 1) pendapatan dari jual-beli, 2) pendapatan bagi hasil, dan 3) pendapatan sewa.

Pendapatan Jual-Beli terdiri dari : 1) Pendapatan Murabahah, yang merupakan pendapatan atas pembiayaan murabahah, 2) Pendapatan Salam, yang merupakan pendapatan atas pembiayaan salam, 3) Pendapatan Istishna, yang merupakan pendapatan atas pembiayaan istishna. Pada pendapatan bagi hasil, pedapatan terbagi atas dua yaitu : 1) Pendapatan Mudharabah, yang merupakan pendapatan atas pembiayaan mudharabah yang diberikan oleh bank kepada nasabah. 2) Pendapatan Musyarakah, yang merupakan pendapatan atas pembiayaan musyarakah yang diberikan kepada nasabah. Dan Pendapatan Sewa terdiri dari: 1)
Pendapatan Ijarah, 2) Pendapatan Ijarah Muntahiya Bitamlik. (Laksmana, 2009)

Pendapatan Operasional ini merupakan pendapatan utama pada bank syari'ah yang merupakan sumber utama bank syari'ah dalam memperoleh keuntungan (laba) yang besar. Keuntungan (laba) besar yang diperoleh perusahaan belum merupakan ukuran bahwa perusahaan tersebut telah dapat bekerja secara efisien. Dan untuk melihat kinerja perusahaan itu telah bekerja secara efisien, perusahaan dapat mengukurnya dengan menentukan tingkat profitabilitasnya.

Profitabilitas merupakan alat dalam mengukur kemampuan suatu bank dalam menghasilkan laba atau keuntungan selama periode tertentu dengan menggunakan modal dan aset yang tertanam di dalamnya, (Siamad, 1995). Profitabilitas dapat tercermin dari bagaimana efektifitas manajemen bank dalam mengelola dana yang dipercayakan kepadanya untuk dapat menghasilkan laba atau keuntungan. Apabila bank dapat meningkatkan profitabilitasnya, maka bank tidak akan mendapat kesulitan dalam membayar 
hutangnya. Semakin tinggi profitabilitas perusahaan maka semakin mampu perusahaan tersebut dalam mendapatkan laba dan perusahaan juga mampu memberikan return yang diharapkan oleh investor.

Profitabilitas perusahaan dapat dilihat dari berbagai rasio salah satunya ROA (ReturnOn Asset) yang merupakan ukuran efektivitas perusahaan dalam menghasilkan keuntungan dengan aset yang dimilikinya. ROA dianggap lebih valid dalam mengukur kinerja pada suatu perusahaan.

Tahun 1999 Bank Mandiri
konsolidasi dan membentuk tim
pengembangan perbankan syariah yang
bertujuan untuk mengembangkan layanan

perbankan syariah di kelompok perusahaan Bank Mandiri. Tim pengembangan perbankan syariah melakukan konversi PT Bank Susila Bakti dari bank konvensional menjadi bank syariah dan diberi nama PT Bank Syariah Mandiri . PT Bank Syariah Mandiri hadir, tampil dan tumbuh sebagai bank yang mampu memadukan idealisme usaha dengan nilai-nilai rohani, yang melandasi kegiatan operasionalnya. Harmoni antara idealisme usaha dan nilainilai rohani inilah yang menjadi salah satu keunggulan Bank Syariah Mandiri dalam kiprahnya di perbankan Indonesia.

Berdasarkan data dari Bank Syari'ah Mandiri Wisma Mandiri I Jakarta, pendapatan operasional dapat dilihat pada tabel berikut :

Tabel 1. Pendapatan Operasional Utama

Bank Syari'ah Mandiri Wisma Mandiri I Jakarta

Periode 2005-2009 ( Rp. )

\begin{tabular}{|c|c|c|c|}
\hline \multirow{2}{*}{ Tahun } & \multicolumn{3}{|c|}{ Pendapatan Operasional Utama } \\
\hline & Pendapatan Jual-Beli & Pendapatan Bagi Hasil & Pendapatan Sewa \\
\hline 2005 & $\operatorname{Rp} \quad 578,135,679,000$ & Rp $210,444,043,000$ & $\mathrm{Rp} \quad 4,781,485,000$ \\
\hline 2006 & Rp $500,423,563,000$ & Rp 310,064,787,000 & Rp $14,618,537,000$ \\
\hline 2007 & $\operatorname{Rp} 560,920,117,000$ & Rp 464,903,596,000 & Rp $24,713,676,000$ \\
\hline 2008 & Rp $836,501,312,004$ & Rp $703,877,397,539$ & Rp $15,240,458,413$ \\
\hline 2009 & Rp $955,773,139,668$ & Rp $798,583,384,541$ & Rp $15,913,019,709$ \\
\hline
\end{tabular}

Sumber : Bank Syari'ah Mandiri Wisma Mandiri I Jakarta.

Dari Tabel 1 di atas, dapat disimpulkan bahwa pendapatan operasional pada Bank Syari'ah Mandiri Wisma Mandiri I Jakarta, dari tahun 2005 hingga 2009, secara keseluruhan dapat dikatakan meningkat. Tingkat persentase pendapatan operasional utama tahun 2005, yaitu pendapatan jual-beli $73 \%$, pendapatan bagi hasil $27 \%$, dan pendapatan sewa $1 \%$. Tahun 2006 tingkat persentase pendapatan jual-beli $61 \%$, pendapatan bagi hasil $38 \%$, dan pendapatan sewa 2\%. Tahun 2007 tingkat persentase pendapatan jual-beli $53 \%$, pendapatan bagi hasil $44 \%$, dan pendapatan sewa $2 \%$. Tahun 2008 tingkat persentase pendapatan jual-beli 53,77\%, pendapatan bagi hasil $45,25 \%$ dan pendapatan sewa 0,98\%. Tahun 2009 tingkat persentase pendapatan jual-beli $53,99 \%$, pendapatan bagi hasil $45,11 \%$ dan pendapatan sewa $0,90 \%$.
Berdasarkan penelitian Purnamasari (2006), dengan judul "Pengaruh Pendapatan Bagi Hasil Mudharabah Terhadap Profitabilitas Pada BNI Syari'ah", dalam perhitungan menunjukkan bahwa persamaan regresi yaitu $\mathrm{Y}=$ $0,35-0,062 \mathrm{X}$ dengan hubungan yang sangat kuat dan negatif yaitu sebesar $-0,807$ sedangkan besarnya koefisien determinasi sebesar $65,10 \%$, hal ini menunjukkan bahwa perubahan pendapatan bagi hasil mudharabah mempengaruhi perubahan pada profitabilitas sebesar $65,10 \%$. Dari perhitungan tersebut dapat disimpulkan bahwa pendapatan bagi hasil mudharabah berpengaruh negatif terhadap profitabilitas pada BNI Syari'ah. Hal ini dikarenakan adannya perolehan pendapatan yang lebih rendah dibandingkan beban-beban yang terjadi. Namun peneliti ingin melakukan pengembangan terhadap penelitian ini, 
dengan membahas semua unsur dalam pendapatan operasional utama bank syari'ah mandiri, sehingga dapat diketahui lebih jelas bagaimana pengaruh pendapatan operasional terhadap profitabilitas.

Berdasarkan latar belakang di atas, maka permasalahan dalam penelitian ini dapat dirumuskan sebagai berikut :

1. Bagaimanakah pengaruh Pendapatan Jual-Beli, Pendapatan Bagi Hasil, dan Pendapatan Sewa secara parsial terhadap Return On Asset

2. Bagaimanakah pengaruh Pendapatan Jual-Beli, Pendapatan Bagi Hasil, dan Pendapatan Sewa secara simultan terhadap Return On Asset

Adapun tujuan dari penelitian ini adalah :

1. Untuk mengetahui bagaimanakah pengaruh Pendapatan Jual-Beli, Pendapatan Bagi Hasil, dan Pendapatan Sewa secara parsial terhadap Return On Asset.

2. Untuk mengetahui bagaimanakah pengaruh Pendapatan Jual-Beli, Pendapatan Bagi Hasil, dan Pendapatan Sewa secara simultan terhadap Return On Asset.

\section{KERANGKA TEORITIS DAN HIPOTESIS}

Dalam undang-undang perbankan yaitu Undang-Undang Nomor 10 Tahun 1998, dijelaskan bahwa perbankan adalah segala sesuatu yang menyangkut tentang bank, mencakup kelembagaan, kegiatan usaha, serta cara dan proses dalam melaksanakan kegiatan usahanya. Sedangkan bank adalah badan usaha yang menghimpun dana dari masyarakat dalam bentuk simpanan dan menyalurkan kepada masyarakat dalam bentuk kredit dan atau bentukbentuk lainnya dalam rangka meningkatkan tarif hidup rakyat banyak.

Strategi bank dalam menghimpun dana adalah dengan memberikan penarik bagi nasabahnya berupa balas jasa yang menarik dan menguntungkan. Balas jasa tersebut dapat berupa bunga bagi bank yang berdasarkan prinsip konvensional dan bagi hasil untuk bank yang berdasar-kan prinsip syariah. Kemudian penarikan lainnya dapat berupa cendra mata, hadiah, undian, atau balas jasa lainnya, semakin beragam dan meng-untungkan balas jasa yang diberikan, maka akan menambah minat masyarakat untuk menyimpan uangnya. Menurut pasal 1 Undang-Undang No. 4 Tahun 2003 tentang Perbankan, Bank adalah Bank umum dan Bank Perkreditan Rakyat yang melaksanakan kegiatan usaha secara konvensional atau berdasarkan prinsip syariah yang dalam kegiatannya tidak memberikan jasa dalam lalu lintas pembayaran.

Bank Syari'ah atau bank Islam adalah salah satu bentuk dari perbankan nasional yang mendasarkan operasionalnya pada syariat hukum islam (Roesmara, 2007). Menurut Sudarsono (2004) Bank Syari'ah adalah lembaga keuangan yang usaha pokoknya memberikan kredit dan jasa lain dalam lalu lintas pembayaran serta peredaran uang yang beroperasi dengan prinsip-prinsp syari'ah. Defenisi bank syari'ah menurut Muhammad (2002) adalah lembaga keuangan yang beroperasi dengan tidak mengandalkan pada bunga yang usaha pokoknya memberikan pembiayaan dan jasa-jasa lainnya dalam lalu lintas pembayaran serta peredaran uang yang beroperasi dengan prinsip-prinsp syari'ah. Bank syari'ah dalam UU No 10 Tahun 1998 tentang perbankan Pasal 1 tidak didefinisilan secara rinci. Namun dapat ditarik pengertian bahwa bank syari'ah adalah bank umum atau bank perkreditan rakyat yang melaksanakan kegitan usahanya berdasarkan prinsip syari'ah yang dalam kegiatannya memberikan jasa dalam lalu lintas pembayarannya. Algaoud dan Lewis (2001) menyatakan : perbankan islam memberikan layanan bebas bunga kepada nasabahnya. Pembayaran dan penarikan bunga dilarang dalam semua transaksi. Islam melarang kaum muslimin menarik atau membayar bunga (riba).

Ibrahim (1997), dalam Arifin (2003), menyatakan bahwa bank syari'ah didirikan 
dengan tujuan untuk mempromosikan dan mengembangkan penerapan prinsip-prinsip islam, syari'ah dan tradisinya kedalam transaksi keuangan dan perbankan serta bisnis lain yang terkait. Prinsip utama yang diikuti bank islam adalah pelarangan riba, melakukan kegiatan usaha dan perdagangan berdasarkan keuntungan yang sah dan memberikan zakat.

Sementara bank yang beroperasi sesuai dengan prinpsip syari'ah islam adalah bank yang dalam beroperasinya itu mengikuti ketentuan-ketentuan syari'ah islam, khususnya yang menyangkut tata cara bermuamalah secara islam. Dikatakan lebih lanjut, dalam tata cara bermuamalah itu dijauhi praktek yang dikhawatirkan mengandung unsur riba diisi dengan kegiatan-kegiatan investasi atas dasar bagi hasil dan pembiayaan perdagangan.

Dari uraian di atas dapat ditarik kesimpulan bahwa bank syari'ah adalah bank yang dalam melaksanakan aktivitasnya dalam pemberian jasa dan lainnya berdasarkan prinsip syari'ah islam, seperti menghindari penggunaan instrument bunga (riba) dan beroperasi dengan prinsip bagi hasil.

\section{Prinsip Dasar Perbankan Syari'ah}

Pada dasarnya prinsip bank syariah menghendaki semua dana yang diperoleh dalam sistem perbankan syari'ah dikelola dengan integritas tinggi dan sangat hatihati.

a) Shiddiq, memastikan bahwa pengelolaan bank syariah dilakukan dengan moralitas yang menjunjung tinggi nilai kejujuran. Dengan nilai ini pengelolaan diperkenankan (halal) serta menjauhi cara-cara yang meragukan (subhat) terlebih lagi yang bersifat dilarang (haram).

b) Tabligh, secara berkesinambungan melakukan sosialisasi dan mengedukasi masyarakat mengenai prinsipprinsip, produk dan jasa perbankan syariah. Dalam melakukan sosialisasi sebaiknya tidak hanya mengedepankan pemenuhan prinsip syariah semata, tetapi juga harus mampu mengedukasi masyarakat mengenai manfaat bagi pengguna jasa perbankan syariah.

c) Amanah, menjaga dengan ketat prinsip kehati-hatian dan kejujuran dalam mengelola dana yang diperoleh dari pemilik dana (shahibul maal) sehingga timbul rasa saling percaya antara pemilik dana dan pihak pengelola dana investasi (mudharib).

d) Fathanah, memastikan bahwa pegelolaan bank dilakukan secara profesional dan kompetitif sehingga menghasilkan keuntungan maksimum dalam tingkat resiko yang ditetapkan oleh bank. Termasuk di dalamnya adalah pelayanan yang penuh dengan kecermatan dan kesantunan (ri'ayah) serta penuh rasa tanggung jawab (mas'uliyah).

\section{Sistem Operasional Bank Syariah}

Pada sistem operasi bank syariah, pemilik dana menanamkan uangnya di bank tidak dengan motif mendapatkan bunga, tapi dalam rangka mendapatkan keuntungan bagi hasil. Dana nasabah tersebut kemudian disalurkan kepada mereka yang membutuhkan (misalnya modal usaha), dengan perjanjian pembagian keuntungan sesuai kesepakatan. Sistem operasional tersebut meliputi:

\section{Sistem Penghimpunan Dana}

Metode penghimpunan dana yang ada pada bank-bank konvensional didasari teori yang diungkapkan Keynes yang mengemukakan bahwa orang membutuhkan uang untuk tiga kegunaan, yaitu fungsi transaksi, cadangan dan investasi. Teori tersebut menyebabkan produk penghimpunan dana disesuaikan dengan tiga fungsi tersebut, yaitu berupa giro, tabungan dan deposito.

Berbeda halnya dengan hal tersebut, bank syariah tidak melakukan pendekatan tunggal dalam menyediakan produk penghimpunan dana bagi nasabahnya. Pada dasarnya, dilihat dari sumbernya, dana bank syariah terdiri atas:

a. Modal

Modal adalah dana yang diserahkan oleh para pemilik (owner). Dana modal dapat digunakan untuk pembelian gedung, tanah, perlengkapan, dan sebagainya yang secara tidak langsung menghasilkan (fixed asset/non earning asset). Selain itu, modal juga dapat digunakan untuk hal-hal yang produktif, yaitu disalurkan menjadi pembiayaan. 
Pembiayaan yang berasal dari modal, hasilnya tentu saja bagi pemilik modal, tidak dibagikan kepada pemilik dana lainnya.

Mekanisme penyertaan modal pemegang saham dalam perbankan syariah, dapat dilakukan melalui musyarakah fi sahm asy-syarikah atau equity participation pada saham perseroan bank.

b. Titipan (Wadi'ah)

Salah satu prinsip yang digunakan bank syariah dalam memobilisasi dana adalah dengan menggunakan prinsip titipan. Akad yang sesuai dengan prinsip ini ialah al-wadi'ah.

Dalam prinsip ini, bank menerima titipan dari nasabah dan bertanggung jawab penuh atas titipan tersebut. Nasabah sebagai penitip berhak untuk mengambil setiap saat, sesuai dengan ketentuan yang berlaku.

c. Investasi (Mudharabah)

Akad yang sesuai dengan prinsip investasi adalah mudharabah yang mempunyai tujuan kerjasama antara pemilik dana (shahibul maal) dengan pengelola dana (mudharib), dalam hal ini adalah bank. Pemilik dana sebagai deposan di bank syariah berperan sebagai investor murni yang menanggung aspek sharing risk dan return dari bank. Deposan, dengan demikian bukanlah lender atau kreditor bagi bank seperti halnya pada bank konvensional.

2. Sistem Penyaluran Dana (Financing)

Produk penyaluran dana di bank syariah dapat dikembangkan dengan tiga model, yaitu:

a. Transaksi pembiayaan yang ditujukan untuk memiliki barang dilakukan dengan prinsip jual beli.

Prinsip jual beli ini dikembangkan menjadi bentuk pembiayaan pembiayaan murabahah, salam dan istishna'.

b. Transaksi pembiayaan yang ditujukan untuk mendapatkan jasa dilakukan dengan prinsip sewa (Ijarah). Transaksi ijarah dilandasi adanya pemindahan manfaat. Jadi pada dasarnya prinsip ijarah sama dengan prinsip jual beli, namun perbedaannya terletak pada obyek transaksinya. Bila pada jual beli obyek transaksinya adalah barang, maka pada ijarah obyek transaksinya jasa.

c. Transaksi pembiayaan yang ditujukan untuk usaha kerjasama yang ditujukan guna mendapatkan sekaligus barang dan jasa, dengan prinsip bagi hasil.

Prinsip bagi hasil untuk produk pembiayaan di bank syariah dioperasionalkan dengan pola-pola musyarakah dan mudharabah.

\section{Pendapatan Operasional Utama}

Pendapatan operasional utama bank syariah adalah pendapatan dari penyaluran dana pada investasi yang dibenarkan syariah yaitu pendapatan penyaluran dana prinsip jual beli, bagi hasil, dan prinsip sewa. Dan prinsip pembagian usahanya ada dua yaitu : berdasarkan prinsip bagi hasil (Revenue Sharing ), dan berdasarkan prinsip bagi untung ( profit Sharing ).

Pada Revenue Sharing, besarnya pendapatan yang dibagikan dalam perhitungan distribusi hasil usaha dengan prinsip revenue sharing ini adalah pendapatan (revenue) dari pengelolaan dana (penyaluran) sebesar porsi dana mudharabah (investasi tidak terikat) yang dihimpun tanpa adanya pengurangan beban-beban yang dikeluarkan oleh bank syariah.

Sedangkan pada profit Sharing, penerapan distribusi hasil usaha dengan prinsip bagi untung (profit sharing) bukanlah hal yang mudah, karena pihak deposan harus siap menerima bagian kerugian apabila dalam pengelolaan dana mudharabah mengalami kerugian yang bukan akibat dari kelalaian mudharib sehingga uang yang diinvestasikan pada bank syariah menjadi berkurang. Di lain pihak, bank syariah sendiri harus secara jujur dan transparan menyampaikan bebanbeban yang akan ditanggung dalam pengelolaan dana mudharabah, seperti membuat dan menentukan dengan tegas dan jelas beban yang akan dibebankan dalam pengelolaan dana mudharabah baik beban langsung maupun beban tidak langsung. Apabila bank syariah menerapkan pembagian hasil usaha berdasarkan prinsip bagi untung (profit sharing), bank syariah harus membuat dua laporan laba rugi yang terpisah, yaitu laporan laba rugi bank sebagai institusi keuangan syariah dan 
laporan pengelolaan dana mudarabah dimana bank sebagai mudharib.

\section{Pendapatan Jual-Beli}

Pendapatan jual-beli merupakan pendapatan yang berasal dari pembiayaan dengan prinsip jual-beli, prinsip ini merupakan suatu sistem yang menerapkan tata cara jual-beli, dimana bank akan membeli terlebih dahulu barang yang dibutuhkan atau mengangkat nasabah sebagai agen bank melakukan pembelian barang atas nama bank, kemudian bank menjual barang tersebut kepada nasabah dengan harga beli ditambah keuntungan (margin).

Implikasinya berupa :

\section{1) Al-Murabahah}

Murabahah adalah akad jual beli dimana penyerahan barang dilakukan di awal akad. Bank menetapkan harga jual barang yaitu harga pokok perolehan barang ditambah sejumlah margin keuntungan bank. Harga jual telah disepakati di awal akad tidak boleh berubah selama jangka waktu pembiayaan.

\section{2) Salam}

Salam adalah akad jual beli di mana barang yang diperjualbelikan belum ada. Pembayaran barang dilakukan di depan oleh bank namun penyerahan barang oleh nasabah dilakukan secara tangguh karena memerlukan waktu untuk proses pengadaannya. Lazimnya setelah barang tersebut diserahkan kepada bank maka bank akan menjualnya kepada pembeli yang telah memesan sebelumnya. Praktik ini disebut salam parallel karena melibatkan pemesan dan bank, serta bank dan pelaksana yang bertanggung jawab atas realisasi pesanan tersebut.

\section{3) Istishna}

Istishna adalah akad jual beli yang polanya sama dengan pembiayaan salam, namun berbeda dalam pola pembayarannya. Bila salam pembayar annya dilakukan didepan akad, maka pembayarannya dalam istishna dapat dilakukan secara bertahap sesuai kesepakatan.

\section{Pendapatan Bagi-Hasil}

Pendapatan bagi hasil merupakan pendapatan yang berasal dari pembiayaan dengan sistem bagi hasil. Sistem ini adalah suatu sistem yang meliputi tatacara pembagian hasil usaha antara penyedia dana dengan pengelola dana.

Bentuk produk yang berdasarkan prinsip ini adalah :

\section{1) Al-Mudharabah}

Al-Mudharabah adalah akad kerjasama usaha antara dua pihak dimana pihak pertama (shahibul maal) menyediakan seluruh (100\%) modal, sedangkan pihak lainnya menjadi pengelola (mudharib).

Keuntungan usaha secara mudharabah dibagi menurut kesepakatan yang dituangkan dalam kontrak, sedangkan apabila rugi ditanggung oleh pemilik modal selama kerugian itu bukan akibat kelalaian si pengelola. Seandainya kerugian ini diakibatkan karena kecurangan atau kelalaian si pengelola, si pengelola harus bertanggung jawab atas kerugian tersebut.

\section{Pendapatan Sewa (Al-Ijarah)}

Al-ijarah adalah akad pemindahan hak guna atas barang atau jasa, melalui pembayaran upah sewa, tanpa diikuti dengan pemindahan hak kepemilikan atas barang itu sendiri. Alijarah terbagi kepada dua jenis: (1) Ijarah, sewa murni. (2) ijarah al muntahiya bitamlik merupakan penggabungan sewa dan beli, dimana si penyewa mempunyai hak untuk memiliki barang pada akhir masa sewa.

Ijarah murni adalah suatu transaksi sewa-menyewa objek tanpa adanya perpindahan kepemilikan yaitu objek tetap dimiliki oleh si pemilik. Ijarah al muntahiya bitamlik adalah suatu transaksi sewa-menyewa dimana terdapat pilihan bagi si penyewa untuk memiliki barang yang di sewa di akhir masa sewa melalui mekanisme sale and lease back.

Pengertian profitabilitas adalah kemampuan suatu perusahaan untuk menghasilkan laba dibandingkan dengan 
modal yang harus digunakan dinyatakan dalam persentase (Siamad,1995: 65). Menurut Riyanto (1997:19) Profitabilitas adalah rasio yang menunjukan perbandingan antara laba dengan aktiva atau modal yang menghasilkan laba tersebut. Sedangkan Menurut Weston (1990: 92) Profitabilitas adalah kemampuan perusahaan untuk memperoleh laba dari seluruh penggunaan dana yang ditanamkan dalam peruahaan. Rasio untuk mengukur aktivitas manajemen yang ditunjukan oleh laba yang dihasilkan dari perusahaan dan investasi perusahaan

Dari definisi diatas maka dapat disimpulkan bahwa profitabilitas itu merupakan kemampuan-kemampuan perusahaan untuk menghasilkan laba atau keuntungan selama periode tertentu dibandingkan dengan aktiva dan modal yang dinyatakan dalam persentase yang merupakan hasil lebih dari berbagai kebijaksanaan dan keputusan yang diterapkan oleh perusahaan. Bagi suatu perusahaan, di samping laba tingkat profitabilitas merupakan masalah yang penting, sebab laba yang besar saja belum merupakan ukuran bahwa perusahaan tersebut telah dapat bekerja secara efisien.

\section{Rasio Profitabilitas}

Ada beberapa rasio yang digunakan untuk mengukur tingkat profitabilitas pada sebuah perusahaan, yaitu(Laksmana,2009):

a. GPM (Gross Profit Margin)

$$
\begin{aligned}
& \text { GPM }=\frac{\text { Laba Bersih }}{\text { Modal Sendiri }} \times 100 \% \\
& \hline \text { GPM (Gross Profit Margin) } \\
& \text { menunjukkan berapa persen } \\
& \text { keuntungan kotor perusahaan dari } \\
& \text { setiap penjualan produk. }
\end{aligned}
$$

b. NPM (Net Profit Margin)

$$
\mathrm{NPM}=\frac{\text { Laba Bersih }}{\text { Penjualan }} \times 100 \%
$$

NPM (Net Profit Margin) menunjukan berapa keuntungan bersih perusahaan pada aktifitas penjualan produk. Rasio ini telah memperhitungkan biaya-biaya sebagai pengurang pendapatan. c. ROA (Return On Asset)

$$
\mathrm{ROA}=\frac{\text { Laba Bersih }}{\text { Total Aktiva }} \times 100 \%
$$

ROA (Return On Asset) menunjukan kemampuan perusahaan untuk mencetak keuntungan dari setiap Rp 1 aset yang digunakan. Rasio ini juga menggambarkan seberapa efisien operasional perusahaan dalam memanfaatkan aktivanya. Bila nilai ROA $15 \%$ artinya perusahaan mampu mendapatkan keuntungan $15 \%$ dari setiap $1 \mathrm{Rp}$ aset perusahaan. Untuk menilai kinerja perusahaan, nilai ROA bisa dibandingkan dengan tingkat ratarata suku bunga simpanan bank konvensional atau rata-rata tingkat kembalian bagi hasil investasi pendanaan bank syariah. Sebagai contoh bila ROA $15 \%$ dan bila ratarata tingkat suku bunga simpanan bank dan imbal bagi hasil dana bank syariah sebesar 5\%, dapat diambil kesimpulan bahwa kinerja perusahaan lebih baik karena memperoleh hasil yang lebih tinggi dari pada bunga atau bagi hasil produk dana perbankan.

d. ROE (Return On Equity)

$$
\begin{array}{|l}
\text { ROE }=\frac{\text { Laba Bersih }}{\text { Modal Sendiri }} \times 100 \% \\
\text { ROE } \text { adalah rasio yang }
\end{array}
$$
menggambarkan keuntungan yang dapat diberikan kepada pemilik perusahaan atas modal yang sudah di investasikan. Jika rasio $\mathrm{ROE}=10 \%$ berarti pemilik perusahaan mendapatkan keuntungan sebesar $10 \%$ dari setiap satu rupiah yang di investasikan sebagai modal usaha. Nilai ROE juga menjadi tolok ukur mengenai tingkat pengembalian keuntungan dengan dibandingkan suku bunga simpanan bank dan imbal bagi hasil dana bank syariah. Bila ROE lebih tinggi maka perusahaan mampu memberikan keuntungan yang lebih baik dibandingkan bila dana modal ditempatkan dalam bentuk tabungan atau deposito di bank. 


\section{Kerangka Konseptual}

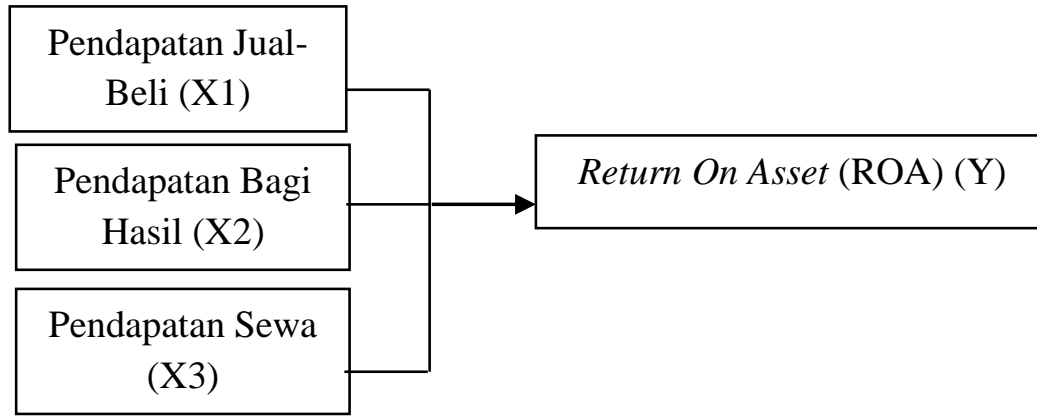

\section{Hipotesis}

Dalam penelitian ini dapat dirumuskan hipotesis, sebagai berikut:

$\mathrm{H}_{1}=$ Pendapatan Jual-Beli, Pendapatan Bagi Hasil, dan Pendapatan Sewa secara parsial berpengaruh signifikan terhadap Return On Asset (ROA).

$\mathrm{H}_{2}=$ Pendapatan Jual-Beli, Pendapatan Bagi Hasil, dan Pendapatan Sewa secara simultan berpengaruh signifikan terhadap Return On Asset (ROA).

\section{METODOLOGI}

Adapun yang menjadi objek dalam penelitian ini adalah Bank Syariah Mandiri yang beralamat di Wisma Mandiri I, Jl. MH. Thamrin No. 5 Jakarta 10340 Indonesia. Data yang dibutuhkan dalam penelitin ini berupa laporan keuangan tahunan pada Bank Syariah Mandiri Wisma Mandiri I Jakarta, dari tahun 2005 hingga 2009.

\section{Definisi dan Operasional Variabel}

Variabel independen adalah variabel yang secara sendiri-sendiri atau bersamasama mempengaruhi variabel dependen. Dalam penelitian ini yang menjadi variabel independen yaitu : (Laksmana : 2009);

1. Pendapatan Jual-Beli

Pendapatan jual-beli merupakan pendapatan yang berasal dari pembiayaan dengan prinsip jual-beli, prinsip ini merupakan suatu sistem yang menerapkan tata cara jual-beli, dimana bank akan membeli terlebih dahulu barang yang dibutuhkan atau mengangkat nasabah sebagai agen bank melakukan pembelian barang atas nama bank, kemudian bank menjual barang tersebut kepada nasabah dengan harga beli ditambah keuntungan (margin).
2. Pendapatan Bagi Hasil

Pendapatan bagi hasil merupakan pendapatan yang berasal dari pembiayaan dengan sistem bagi hasil. Sistem ini adalah suatu sistem yang meliputi tatacara pembagian hasil usaha antara penyedia dana dengan pengelola dana.

3. Pendapatan Sewa (Al-ijarah)

$$
\text { Al-ijarah adalah akad }
$$

pemindahan hak guna atas barang atau jasa, melalui pembayaran upah sewa, tanpa diikuti dengan pemindahan hak kepemilikan atas barang itu sendiri.

Variabel dependen adalah variabel yang dipengaruhi oleh variabel independen. Dalam penelitian ini yang merupakan variabel dependen adalah :

Return On Asset yang merupakan perbandingan antara laba sebelum bunga dan pajak dengan total aktiva. (Husnan : 1998);

$$
R O A=\frac{\text { labasebelumpajak }}{\text { totalaktiva }} \times 100 \%
$$

Teknik pengumpulan data pada penelitian ini adalah data sekunder yaitu data-data pokok yang bersumber dari Laporan Keuangan Tahunan Bank Syari'ah Mandiri Mandiri Wisma Mandiri I Jakarta. Data dikumpulkan melalui www.banksyariahmandiri.com)

\section{Teknik Analisa Data}

Metode statistik deskriptif adalah metode statistik yang digunakan untuk menggambarkan atau mendeskripsikan data yang telah dikumpulkan menjadi informasi (Kuncoro, 2003:172). Statistik deskriptif dalam penelitian ini yaitu menjelaskan tentang pendapatan jual-beli, pendapatan 
bagi hasil, dan pendapatan sewa dengan return on asset.

\section{Koefisien Korelasi}

Koefisien korelasi digunakan untuk mengukur keeratan hubungan antara dua variabel (Sugiyono,2002). Dalam penelitian ini koefisien korelasi digunakan unuk mencari hubungan antara pendapatan jual-beli, pendapatan bagi hasil, dan pendapatan sewa dengan return on asset dengan menggunakan program SPSS versi 16 for windows.

\section{Analisa Regresi Berganda}

Analisa regresi berganda adalah suatu teknik statistik yang digunakan untuk mengetahui seberapa besar pengaruh variabel bebas terhadap variabel terikat (Kuncoro : 2003)

$\mathrm{Y}=\alpha+\mathrm{b}_{1} \mathrm{X}_{1}+\mathrm{b}_{2} \mathrm{X}_{2}+\mathrm{b}_{3} \mathrm{X}_{3}+\mathrm{e}$

Keterangan :

$\mathrm{Y}=$ Return On Asset

$\alpha=$ Koefisien Konstanta

$\mathrm{b}_{1}=$ koefisien regresi variabel independen 1

$\mathrm{X}_{1}=$ Pendapatan Jual-Beli

$\mathrm{X}_{2}=$ Pendapatan Bagi Hasil

$\mathrm{b}_{2}=$ koefisien regresi variabel independen 2

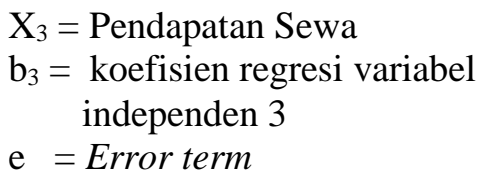

Tujuan menggunakan analisa regresi berganda dalam analisa penelitian ini adalah untuk pengujian hipotesis penelitian mengenai pengaruh varibel pendapatan jual-beli, pendapatan bagi hasil, dan pendapatan sewa terhadap return on asset baik secara parsial maupun simultan.

Secara parsial dilakukan dengan uji $\mathrm{t}$ sedangkan secara simultan melalui uji $\mathrm{F}$ dengan signifikansi $5 \%$.

Jika sig $<\alpha$ : Ho ditolak dan Ha diterima, berarti terdapat pengaruh pendapatan operasional terhadap return on asset,

Jika sig $>\alpha$ : Ho diterima dan Ha ditolak, berarti tidak terdapat pengaruh pendapatan operasional terhadap return on asset.

\section{HASIL DAN PEMBAHASAN \\ Hasil}

Pada Tabel 2 berikut, disajikan perhitung an perkembangan Pendapatan Jual-Beli Pada Bank Syariah Mandiri Wisma Mandiri Jakarta tahun 2005 sampai dengan 2009.

Tabel 2. Perkembangan Pendapatan Jual-Beli Bank Syariah Mandiri Wisma Mandiri Jakarta

Tahun 2005 - 2009.

\begin{tabular}{|c|cc|c|}
\hline Tahun & \multicolumn{2}{|c|}{ Pendapatan Jual-Beli } & Perkembangan Pendapatan \\
\hline 2005 & $\mathrm{Rp}$ & $578,135,679,000$ & - \\
\hline 2006 & $\mathrm{Rp}$ & $500,423,563,000$ & $-13.44 \%$ \\
\hline 2007 & $\mathrm{Rp}$ & $560,920,117,000$ & $12.09 \%$ \\
\hline 2008 & $\mathrm{Rp}$ & $836,501,312,004$ & $49.13 \%$ \\
\hline 2009 & $\mathrm{Rp}$ & $955,773,139,668$ & $14.26 \%$ \\
\hline
\end{tabular}

Sumber : Bank Syariah Mandiri Wisma Mandiri Jakarta.

Dari tabel 2 dapat dilihat pertumbuhan dalam Pendapatan Jual-Beli dari tahun 2005 sampai tahun 2009. Pada Perkembangan pendapatan tahun $\mathrm{x}$ $=\frac{\text { Pendapatan Jual Beli th }(\mathrm{x})-\text { pendapatan Jual Beli th }(\mathrm{x}-1)}{\text { Pendapatan Jual Beli th }(\mathrm{x}-1)} \times 100 \%$

Dengan menggunakan rumus di atas diperoleh penurunan pendapatan pada tahun 2006 sebesar (13.44\%), tahun 2007 terjadi peningkatan sebesar $12.09 \%$, tahun 2008 terjadi peningkatan sebesar $49.13 \%$, tahun 2009 terjadi peningkatan sebesar kolom Perkembangan Pendapatan data diperoleh dengan menggunakan rumus sebagai berikut :
14.26\%. Perkembangan Pendapatan Bagi Hasil.

Pada Tabel ini, penulis menyajikan perhitungan perkembangan Pendapatan Bagi Hasil Pada Bank Syariah Mandiri tahun 2005 sampai dengan tahun 2009: 
Tabel 3. Perkembangan Pendapatan Bagi Hasil Bank Syariah Mandiri Wisma Mandiri Jakarta Tahun 2005 - 2009.

\begin{tabular}{|c|cc|c|}
\hline Tahun & \multicolumn{2}{|c|}{ Pendapatan Jual-Beli } & Perkembangan Pendapatan \\
\hline 2005 & $\mathrm{Rp}$ & $210,444,043,000$ & - \\
\hline 2006 & $\mathrm{Rp}$ & $310,064,787,000$ & $47.34 \%$ \\
\hline 2007 & $\mathrm{Rp}$ & $464,903,596,000$ & $49.94 \%$ \\
\hline 2008 & $\mathrm{Rp}$ & $703,877,397,539$ & $51.40 \%$ \\
\hline 2009 & $\mathrm{Rp}$ & $798,583,384,541$ & $13.45 \%$ \\
\hline
\end{tabular}

Sumber : Bank Syariah Mandiri Wisma Mandiri Jakarta.

Dari tabel 3. di atas dapat dilihat pertumbuhan dalam Pendapatan Bagi Hasil dari tahun 2005 sampai tahun 2009. Pada

Perkembangan pendapatan tahun $\mathrm{x}$
Dengan menggunakan rumus di atas diperoleh peningkatan pendapatan pada tahun 2006 sebesar 47.34\%, tahun 2007 terjadi peningkatan sebesar 49.94\%, Perkembangan Pendapatan Sewa Pada Tabel 4 ini, penulis menyajikan perhitungan perkembangan Pendapatan

Tabel 4. Perkembangan Pendapatan Sewa

Bank Syariah Mandiri Wisma Mandiri Jakarta

Tahun 2005 - 2009.

\begin{tabular}{|c|ccc|c|}
\hline Tahun & \multicolumn{2}{|c|}{ Pendapatan Sewa } & Perkembangan Pendapatan \\
\hline 2005 & $\mathrm{Rp}$ & $4,781,485,000$ & - \\
\hline 2006 & $\mathrm{Rp}$ & $14,618,537,000$ & $205.73 \%$ \\
\hline 2007 & $\mathrm{Rp}$ & $24,713,676,000$ & $69.06 \%$ \\
\hline 2008 & $\mathrm{Rp}$ & $15,240,458,413$ & $-38.33 \%$ \\
\hline 2009 & $\mathrm{Rp}$ & $15,913,019,709$ & $4.41 \%$ \\
\hline
\end{tabular}

Sumber : Bank Syariah Mandiri Wisma Mandiri Jakarta.

Dari tabel 4. di atas dapat dilihat pertumbuhan dalam Pendapatan Sewa dari tahun 2005 sampai tahun 2009. Pada kolom Perkembangan pendapatan tahun $\mathrm{x}$

$$
=\frac{\text { Pendapatan Sewa th }(\mathrm{x}) \text {-Pendapatan Sewa th }(\mathrm{x}-1)}{\text { Pendapatan Sewa th }(\mathrm{x}-1)} \times 100 \%
$$

Dengan menggunakan rumus di atas diperoleh peningkatan pendapatan pada tahun 2006 sebesar 205.73\%, tahun 2007 terjadi peningkatan sebesar $69.06 \%$, tahun 2008 terjadi penurunan sebesar $(38.33 \%)$, tahun 2009 terjadi peningkatan sebesar Perkembangan Pendapatan data diperoleh dengan menggunkan rumus sebagai berikut : $4.41 \%$.

\section{Return On Asset (ROA)}

Pada tabel berikut ini, disajikan hasil perhitungan ROA pada Bank Syariah Mandiri Wisma Mandiri dari tahun 2005 sampai tahun 2009: 
Tabel 5. Return On Asset (ROA) Bank Syariah Mandiri Wisma Mandiri Jakarta Tahun 2005 - 2009

\begin{tabular}{|c|rr|rr|c|}
\hline Tahun & \multicolumn{2}{|c|}{ Laba Sebelum Pajak } & \multicolumn{2}{|c|}{ Total Aktiva } & ROA (Y) \\
\hline 2005 & $\mathrm{Rp}$ & $136,712,076,000$ & $\mathrm{Rp}$ & $8,272,965,277,000$ & $1.65 \%$ \\
\hline 2006 & $\mathrm{Rp}$ & $95,236,624,000$ & $\mathrm{Rp}$ & $9,554,966,615,000$ & $1.00 \%$ \\
\hline 2007 & $\mathrm{Rp}$ & $168,183,151,000$ & $\mathrm{Rp}$ & $12,885,390,558,000$ & $1.31 \%$ \\
\hline 2008 & $\mathrm{Rp}$ & $284,084,927,968$ & $\mathrm{Rp}$ & $17,065,937,985,245$ & $1.66 \%$ \\
\hline 2009 & $\mathrm{Rp}$ & $418,402,513,083$ & $\mathrm{Rp}$ & $22,036,534,515,115$ & $1.90 \%$ \\
\hline
\end{tabular}

Sumber : Bank Syariah Mandiri Wisma Mandiri Jakarta

Dari tabel 5 terlihat bahwa ROA pada Bank Syariah Mandiri Wisma Mandiri Jakarta di atas menggambarkan cukup efisien untuk menghasilkan laba yang lebih maximal dari tahun 2005 sampai dengan tahun 2009. Walaupun ROA ada yang mengalami kenaikan dan penurunan, namun hal ini tidak memberikan dampak buruk bagi bank karena ROA Bank Syariah Mandiri Wisma Mandiri Jakarta menunjukan tanda positif yang berarti suatu bank tersebut mampu untuk menghasilkan laba. ROA dibuat untuk mengetahui kemampuan assets atau aktiva bank dalam menghasilkan laba pada setiap tahunnya apakah mengalami kenaikan atau penurunan dan juga untuk mengetahui apakah telah terjadi efisiensi dalam penggunaan aktiva dalam suatu bank.

\section{Deskripsi Data}

Tabel 6 hasil perhitungan statistik deskriptif dari variabel-variabel yang digunakan dalam penelitian :

Tabel 6. Hasil Statistik Deskriptif

Descriptive Statistics

\begin{tabular}{|l|l|l|l|}
\hline & Mean & Std. Deviation & $\mathrm{N}$ \\
\hline ROA & .0160 & .00548 & 5 \\
Pendapatan Jual Beli & $6.86 \mathrm{E} 5$ & 198207.914 & 5 \\
Pendapatan Bagi Hasil & $4.98 \mathrm{E} 5$ & 250917.286 & 5 \\
Pendapatan Sewa & $1.51 \mathrm{E} 4$ & 7067.741 & 5 \\
\hline
\end{tabular}

Sumber: Pengolahan Data

Dari hasil pengujian statistik deskriptif di atas diperoleh nilai rata-rata (mean), tingkat penyimpangan data (standar deviasi) serta jumlah total populasi untuk masing-masing variabel penelitian. Nilai rata-rata (mean) diperoleh dari jumlah data keseluruhan dalam penelitian dibagi dengan jangka waktu (periode) yang digunakan dalam penelitian.

Berdasarkan tabel 6 diperoleh nilai rata-rata (mean) pada variabel independen Pendapatan Jual-Beli sebesar 6.86E5 dan standar deviasinya 168207.914. Pada variabel independen Pendapatan Bagi Hasil diperoleh nilai rata-rata (mean) sebesar 4.98E5 dengan standar deviasi 250917.286. Sedangkan pada variabel independen Pendapatan Sewa diperoleh nilai rata-rata (mean) 1.51E4 dengan standar deviasi sebesar 7067.741. Selanjutnya pada variabel dependen yaitu Return On Asset (ROA) diperoleh nilai rata-rata (mean) 0.0160 dan standar deviasinya 0.00548 dengan jumlah data 5 tahun.

\section{Analisis Korelasi}

Berdasarkan hasil analisa korelasi antar variabel penelitian yang disajikan pada tabel 7 di atas, terlihat bahwa nilai pendapatan jual-beli adalah 0.717 ini artinya hubungannya kuat dan positif terhadap ROA. Pendapatan bagi hasil dengan nilai 0.401 ini artinya hubungan lemah dan positif terhadap ROA karena 
nilai mendekati 0. Pendapatan sewa dengan nilai -0.596 ini artinya hubungan kuat dan negatif terhadap $R O A$.

Tabel 7. Korelasi Antara Variabel Pendapatan Jual-Beli, Pendapatan Bagi Hasil, dan Pendapatan Sewa.

\begin{tabular}{|l|l|l|l|l|}
\hline \multicolumn{1}{|c|}{ Variabel } & \multicolumn{1}{c|}{ Y } & \multicolumn{1}{c|}{ X1 } & \multicolumn{1}{c|}{ X2 } & \multicolumn{1}{c|}{ X3 } \\
\hline ROA & 1 & - & - & - \\
\hline Pendapatan Jual-Beli & 0.717 & 1 & - & - \\
\hline Pendapatan Bagi Hasil & 0.401 & - & 1 & - \\
\hline Pendapatan Sewa & -0.596 & - & - & 1 \\
\hline
\end{tabular}

Sumber: Data diolah

Sedangkan secara bersamaan, dapat kita lihat pada tabel 8 hubungan variabel independent pendapatan jual-beli, pendapatan bagi hasil, dan pendapatan sewa dengan nilai $\mathrm{R}=0.960$ yang artinya terdapat hubungan yang kuat dan positif terhadap ROA.
Hasil analisa korelasi tersebut disajikan pada tabel berikut:

\begin{abstract}
Analisa Regresi
Untuk mengetahui pengaruh pendapatan jual-beli, pendapatan bagi hasil, dan pendapatan sewa terhadap ROA, digunakan model regresi dari penelitian ini adalah sebagai berikut :

$\mathrm{Y}=\alpha+\mathrm{b}_{1} \mathrm{X}_{1}+\mathrm{b}_{2} \mathrm{X}_{2}+\mathrm{b}_{3} \mathrm{X}_{3}+\mathrm{e}$

Hasil perhitungan regresi untuk model di atas ditunjukkan pada tabel 8 :
\end{abstract}

Tabel 8. Hasil Pengujian Hipotesis

Coefficients $^{a}$

\begin{tabular}{|c|c|c|c|c|c|c|c|c|c|}
\hline \multirow{2}{*}{ Model } & \multicolumn{2}{|c|}{ Unstandardized Coefficients } & Standardized Coefficients & \multirow[b]{2}{*}{$\mathrm{t}$} & \multirow{2}{*}{\multicolumn{2}{|c|}{ Sig. }} & \multicolumn{3}{|c|}{ Correlations } \\
\hline & $B$ & Std. Error & Beta & & & & Zero-order & Partial & Part \\
\hline 1 & (Constant) & -.002 & .027 & & -.076 & .952 & & & \\
\hline & Pendapatan Jual Beli & $4.669 \mathrm{E}-8$ & .000 & 1.690 & .767 & 7.584 & .717 & .608 & .214 \\
\hline & Pendapatan Bagi Hasil & $-2.297 \mathrm{E}-8$ & .000 & -1.052 & -.433 & 3.740 & .401 & -.397 & -.121 \\
\hline & Pendapatan Sewa & $-1.716 \mathrm{E}-7$ & .000 & -.221 & -.226 & .859 & -.596 & -.220 & -.063 \\
\hline
\end{tabular}

Berdasarkan hasil analisa regresi berganda yang disajikan pada tabel coefficients terlihat besarnya nilai konstanta (a) adalah -0.002. Sedangkan nilai koefisien regresi (beta) untuk variabel pendapatan jual-beli adalah 4.669E-8, pendapatan bagi hasil adalah -2.297E-8, pendapatan sewa adalah -1716E-7. Dengan demikian, dapat dikemukakan persamaan regresi berganda adalah:

$$
\mathrm{Y}=-0.002+4.669 \mathrm{E}-8 \mathrm{X}_{1}-2.297 \mathrm{E}-8 \mathrm{X}_{2}-
$$$$
1.716 \mathrm{E}-7 \mathrm{X}_{3}+\mathrm{e}
$$

Persamaan regresi berganda di atas secara statistik dapat diinterpretasikan sebagai berikut:

a) Pendapatan jual-beli sebesar 4.669E-8 dengan tanda positif artinya bahwa, apabila terjadi peningkatan variabel pendapatan jual-beli sebesar Rp. 1 dengan asumsi variabel lain tetap, maka akan mengakibatkan peningkatan ROA sebesar 4.669E-8. Dengan kata lain setiap kenaikan Rp.1 pendapatan jual-beli maka akan meningkatkan tingkat ROA sebesar 0.4669E-9 \%.

b) Pendapatan bagi hasil sebesar 2.297E-8 dengan tanda negatif artinya bahwa, apabila terjadi peningkatan pendapatan bagi hasil sebesar Rp. 1 dengan asumsi variabel lain tetap, maka akan mengakibatkan penurunan ROA sebesar 2.297E-8. Dengan kata lain setiap kenaikan Rp.1 pendapatan bagi hasil, maka akan menurunkan tingkat ROA sebesar 0.2297E-9\%.

c) Pendapatan sewa sebesar $-1.716 \mathrm{E}-7$ dengan tanda negatif artinya bahwa, apabila terjadi peningkatan variabel pendapatan sewa sebesar Rp. 1 
dengan asumsi variabel lain tetap, maka akan terjadi penurunan ROA sebesar 1.716E-7. Dengan kata lain setiap kenaikan Rp.1 pendapatan sewa maka akan menurunkan tingkat ROA sebesar $0.1716 \mathrm{E}-8 \%$.

\section{Uji Koefisien Determinan $\left(\mathbf{R}^{2}\right)$}

Pengujian ini dimaksudkan untuk mengetahui seberapa besarnya pengaruh dari semua variabel independent terhadap variabel dependent dan berapa besar pengaruh yang disebabkan oleh variabel lain yang tidak ikut diteliti dalam penelitian ini.

Tabel 9. Uji Koefesien Determinasi $\left(\mathrm{R}^{2}\right)$

Model Summary ${ }^{\mathrm{b}}$

\begin{tabular}{|l|l|r|r|r|}
\hline Model & \multicolumn{1}{|c|}{$\mathrm{R}$} & R Square & Adjusted R Square & Std. Error of the Estimate \\
\hline 1 & $.960^{\mathrm{a}}$ & .922 & .688 & .00306 \\
\hline
\end{tabular}

a. Predictors: (Constant), Pendapatan Sewa, Pendapatan Jual Beli, Pendapatan Bagi Hasil

b. Dependent Variable: ROA

Sumber: Data diolah

Dari tabel 9 diperoleh $\mathrm{R}$ square adalah 0.922, ini menjelaskan bahwa variabel independen yaitu pendapatan jual-beli, pendapatan bagi hasil, dan pendapatan sewa mempengaruhi variabel dependen yaitu ROA sebesar 92,2\%, sedangkan sisanya $7,8 \%$ dipengaruhi oleh faktor lain yang tidak dibahas dalam penelitian ini.

\section{Uji t}

Untuk melakukan pengujian hipotesis secara parsial uji $t$ tentang pengaruh pendapatan operasional utama yaitu pendapatan jual-beli, pendapatan bagi hasil dan pendapatan sewa terhadap ROA, maka dapat dilihat dari ringkasan hasil analisa regresi yang disajikan pada tabel 8. tabel tersebut memperlihatkan bahwa nilai koefisien regresi (beta) untuk masing - masing variabel bebas adalah sebagai berikut:

a) Nilai koefisien regresi (beta) variabel Pendapatan Jual-Beli adalah 0.767 dengan tingkat signifikansi sebesar 0,584 . Besarnya nilai signifikansi tersebut berada di atas 0,05 . dengan demikian, dapat disimpulkan bahwa pendapatan jual-beli (X1) tidak berpengaruh signifikan terhadap ROA.

b) Nilai koefisien regresi (beta) variabel Pendapatan Bagi Hasil adalah -0.433 dengan tingkat signifikansi sebesar 0,740 . Besarnya nilai signifikansi tersebut berada jauh di atas 0,05. dengan demikian, dapat disimpulkan bahwa pendapatan bagi hasil (X2) tidak berpengaruh signifikan terhadap ROA.

c) Nilai koefisien regresi (beta) variabel Pendapatan Sewa adalah -0.226 dengan tingkat signifikansi sebesar 0,859 . Besarnya nilai signifikansi tersebut berada jauh di atas 0,05 . dengan demikian, dapat disimpulkan bahwa pendapatan sewa (X3) tidak berpengaruh signifikan terhadap ROA.

\section{Uji F}

Tabel 10. Hasil Uji F

ANOVAb

\begin{tabular}{|l|l|r|r|r|r|r|}
\hline Model & \multicolumn{1}{|c|}{ Sum of Squares } & \multicolumn{1}{c|}{$\mathrm{df}$} & \multicolumn{2}{|c|}{ Mean Square } & $\mathrm{F}$ & Sig. \\
\hline 1 & Regression & .000 & 3 & .000 & 3.940 & $.351 \mathrm{a}$ \\
& Residual & .000 & 1 & .000 & & \\
& Total & .000 & 4 & & & \\
\hline
\end{tabular}

a. Predictors: (Constant), Pendapatan Sewa, Pendapatan Jual Beli, Pendapatan Bagi Hasil

b. Dependent Variable: ROA 
Tabel diatas memperlihatkan bahwa nilai $F$ (beta) adalah 3.940 dengan tingkat signifikansi sebesar 0,351. Besarnya nilai signifikansi tersebut berada jauh di atas 0,05. Dengan demikian, dapat disimpulkan bahwa dari Uji $\mathrm{F}$ atau secara simultan pendapatan operasional utama yaitu pendapatan jual-beli, pendapatan bagi hasil dan pendapatan sewa tidak berpengaruh signifikan terhadap ROA dengan tingkat kepercayaan $95 \%$.

\section{Pembahasan}

Sehubungan dengan hipotesis yang telah dikembangkan dimana pendapatan operasional utama yaitu pendapatan jualbeli, pendapatan bagi hasil dan pendapatan sewa baik secara parsial maupun secara simultan berpengaruh signifikan terhadap Return On Asset, hasil analisa statistik dengan menggunakan regresi berganda menunjukkan bahwa secara parsial atau uji $\mathrm{T}$ tidak satupun dari variabel independen (pendapatan jual-beli, pendapatan bagi hasil dan pendapatan sewa) yang berpengaruh signifikan terhadap variabel dependen yaitu ROA. Ini dapat dilihat nilai koefisien regresi (beta) variabel pendapatan jual-beli adalah 0.767 dengan tingkat signifikansi sebesar 0,584. Nilai koefisien variabel pendapatan bagi hasil adalah $-0,433$ dengan tingkat signifikansi sebesar 0,740 , dan nilai koefisien regresi (beta) variabel pendapatan sewa adalah -0.221 dengan tingkat signifikansi sebesar 0,859 . Besarnya nilai signifikansi pendapatan jual-beli, pendapatan bagi hasil dan pendapatan sewa tersebut berada jauh di atas 0,05

Secara simultan atau uji $\mathrm{F}$, hasil analisa statistik dengan menggunakan regresi berganda menunjukkan bahwa secara serentak pendapatan operasional utama yaitu pendapatan jual-beli, pendapatan bagi hasil dan pendapatan sewa tidak berpengaruh signifikan terhadap ROA. Hal ini dapat dibuktikan dengan ditemukan nilai uji-F sebesar 3,940 dengan tingkat signifikansi 0,351 atau yang berada di atas 0,05. dengan demikian hasil penelitian ini memberikan indikasi bahwa pendapatan operasional utama yaitu pendapatan jual-beli, pendapatan bagi hasil dan pendapatan sewa secara bersama-sama tidak berpengaruh signifikan terhadap Return On Asset (ROA) pada Bank Syariah Mandiri Jakarta.

Berdasarkan penelitian yang dilakukan Purnamasari 2006 tentang Pengaruh Pendapatan Bagi Hasil Mudharabah Terhadap Profitabilitas Pada BNI Syari'ah, yang menemukan bahwa pendapatan bagi hasil mudharabah berpengaruh negatif terhadap profitabilitas pada BNI Syari'ah, namun tidak dijelaskan apakah pendapatan bagi hasil mudharabah berpengaruh signifikan terhadap profitabilitas. Sejalan dengan penelitian ini bahwa pendapatan bagi hasil juga berpengaruh negatif terhadap ROA, dan pengembangan yang dilakukan dalam penelitian ini menghasilkan bahwa pendapatan operasional utama yaitu pendapatan jual-beli, pendapatan bagi hasil dan pendapatan sewa secara bersama-sama tidak berpengaruh signifikan terhadap ROA.

Dalam melakukan Pembiayaan Jual Beli, Pembiayaan Bagi Hasil dan Pembiayaan Sewa tentunya bank menginginkan Pendapatan yang diterima besar. Meskipun tingkat pembiayaan tersebut tinggi belum tentu pendapatan yang diterima bank akan tinggi pula, karena keuntungan dari pembiayaan tersebut tidak semua diakui sebagai laba yang diperoleh perusahaan, tetapi banyak digunakan untuk ekspansi usaha seperti bebanbeban yang terjadi, maka pendapatan yang diterima bank akan berkurang. Jadi, bank sangat memperhatikan variabel independen Pendapatan JualBeli, Pembiayaan Bagi Hasil dan Pembiayaan Sewa dalam melakukan pengukuran terhadap tingkat Return On Asset (ROA). 


\section{SIMPULAN DAN IMPLIKASI PENELITIAN \\ Simpulan}

Berdasarkan hasil penelitian, maka dapat ditarik suatu kesimpulan penelitian ini sebagai berikut:

1. Berdasarkan hasil uji t, pengujian hipotesa pertama variabel independen Pendapatan Jual-Beli diperoleh hasil signifikan sebesar 0.584. Nilai sig 0.584 tersebut berada di atas nilai alpha (0.05). Ini berarti Ho diterima dan $\mathrm{Ha}$ ditolak, sehingga dapat disimpulkan bahwa Pendapatan JualBeli tidak berpengaruh signifikan terhadap Return On Asset.

2. Berdasarkan hasil uji t, pengujian hipotesa yang kedua yaitu dengan variabel independen Pendapatan Bagi Hasil memberikan kesimpulan bahwa Pendapatan Bagi Hasil tidak berpengaruh signifikan terhadap Return On Asset (ROA). Hal ini terlihat dari nilai signifikan yang diperoleh sebesar 0.740 lebih besar dari nilai alpha (0.05). Ini berarti Ho diterima dan Ha ditolak.

3. Berdasarkan hasil uji t, hipotesa yang ketiga menggunakan variabel independen Pendapatan Sewa diperoleh hasil signifikan 0.859 . Nilai sig 0.859 tersebut berada di atas nilai alpha (0.05). Ini berarti Ho diterima dan $\mathrm{Ha}$ ditolak, sehingga dapat disimpulkan bahwa variabel independen Pendapatan Sewa tidak berpengaruh signifikan terhadap Return On Asset.

4. Berdasarkan hasil uji $\mathrm{F}$, hipotesa yang keempat dengan tiga variabel independen yaitu Pendapatan JualBeli, Pendapatan Bagi Hasil, dan Pendapatan Sewa secara simultan disimpulkan tidak memiliki pengaruh yang signifikan terhadap variabel dependen Return On Asset. Indikasi ini dapat terlihat dari nilai signifikan (0.351) yang berada di atas nilai alpha 0.05. Oleh karena itu, Ho diterima dan Ha ditolak.

\section{Implikasi Penelitian}

Berdasarkan hasil penelitian, maka implikasinya bagi perusahaan dan peneliti berikutnya sebagai berikut:

1. Berdasarkan hasil penelitian ini maka disarankan kepada manajemen perusahaan (Bank Syariah Mandiri Wisma Mandiri Jakarta) agar tidak hanya pendapatan operasional utama saja yang diperhatikan tetapi pendapatan operasional lainnya juga harus dipertimbangkan.

2. Diharapkan Bank Syariah Mandiri Wisma Mandiri Jakarta bahwa dalam memberikan pembiayaan, sebaiknya memperhatikan jenis pembiayaan apa yang akan diberikan kepada nasabah. Dari penelitian yang dilakukan ini sebaiknya Bank Syariah Mandiri Wisma Mandiri Jakarta lebih memprioritaskan atas Pembiyaan JualBeli dibandingkan Pembiayaan Bagi Hasil dan Pembiayaan Sewa.

3. Untuk penelitian selanjutnya sebaiknya mengambil data berdasarkan periode atau jangka waktu yang lebih lama 10 tahun atau mengambilnya dalam bentuk data bulanan, agar dapat memperhatikan bagaimana pengaruh pendapatan operasional utama secara lebih jelas.

\section{DAFTAR PUSTAKA}

Algoud, Latifa M. and Lewis, Mervynk. 2001. Perbankan Syariah, Prinsip, Praktik, dan Prospek. Serambi Jakarta.

Arifin, Zainal. 2003. Dasar-Dasar Bank Syariah. Jakarta: Alvabet.

Hidayat, Taufik. 2004. Analisis Faktorfaktor yang Mempengaruhi Laju Pertumbuhan Modal Sendiri pada Perusahaan Properti dan Real Estate yang Terdaftar di BEJ Tahun 2000-2002. Skripsi Program Sarjana UPN Yogyakarta.

Kasmir. 2008. Bank dan Lembaga Keuangan Lainnya, Edisi Revisi.Jakarta: PT. RajaGrafindo Persada.

Kuncoro, Mudrajad dan Suhardjono. 2003. Manajemen Perbankan, Teori dan Aplikasinya. Yogyakarta: BPFE. 
Lakmana, Yusak. 2009. Account Officer Bank Syariah. Jakarta: PT. Elex Media Komputindo.

Muhamad. 2002. Pengantar Akuntansi Syariah. Jakarta: Salemba Empat, Edisi Pertama.

Purnamasari, Dian. 2007. Pengaruh Pendapatan Bagi Hasil Mudharabah Terhadap Profitabilitas Pada BNI Syariah. Universitas Islam Indonesia. tidak dipublikasikan.

Riyanto, Bambang. 1997. Dasar-dasar Pembelanjaan Perusahaan. Yogyakarta:

BPFE.

Roesmara Duddy. 2007. Buletin Ekonomika dan Bisnis Islam. Yogyakara: FEB UGM.

Siamad. 1995. Manajemen Bank Umum. Jakarta: Intermedia.
Siamat, Dahlan.2001. Manajemen Lembaga Keuangan. Edisi Ketiga. Jakarta : LPFE UI.

Suad Husnan \& Pudjiastuti. 1998. Dasardasar Manajemen Keuangan, Yogyakarta:UPP AMP YKPN.

Sugiyono. 2002. Metode Penelitian Administrasi. Banding: Alfa Beta.

Syafi'l, Antonio. 2001. Bank Syariah Dari Teori Ke Praktek. Jakarta: Gema Insani Press.

Sudjana. 1996. Metode Statistika. Bandung : Tarsito.

Undang-Undang Nomor 10 Tahun 1998 Tentang Perbankan.

Undang-Undang Nomor 4 Tahun 2003 Tentang Perbankan.

Weston, J. Fred and Brigham. 1990. DasarDasar Manajemen Keuangan. Jakarta: Binarupa Aksara.

www.banksyariahmandiri.com. 